\title{
KOMUNIKASI LINGKUNGAN PENGELOLAAN SAMPAH PADA BANK SAMPAH DI TANGERANG SELATAN
}

\author{
Mirza Shahreza $^{1}$, Sarwititi Sarwoprasodjo², Hadi Susilo Arifin ${ }^{3}$, Dwi Retno Hapsari ${ }^{4}$ \\ Sekolah Pascasarjana IPB, Fakultas Ekologi Manusia \\ Departemen Pengelolaan Sumberdaya Alam dan Lingkungan, IPB University \\ Jl. Raya Dramaga, Kampus IPB Dramaga Bogor, Jawa Barat, 16680, Indonesia \\ No. Telp./HP: ${ }^{1} 081519405934,{ }^{2} 08129547486,{ }^{3} 0811117720,{ }^{4} 085216167667$ \\ E-mail: ${ }^{1}$ mirzashahreza@gmail.com, ${ }^{2}$ sarwititi@apps.ipb.ac.id, ${ }^{3}$ hsarifin@apps.ipb.ac.id, ${ }^{4}$ retnokpm@apps.ipb.ac.id
}

Naskah diterima tanggal 22 Februari 2020, direvisi tanggal 9 Agustus 2020, disetujui tanggal 31 Agustus 2020

\section{ENVIRONMENTAL COMMUNICATIONS WASTE MANAGEMENT AT THE WASTE BANK IN SOUTH TANGERANG}

\begin{abstract}
This research aims to describe waste management's environmental communication in the waste bank among South Tangerang stakeholders. This study used a qualitative descriptive approach where data were obtained from observation and in-depth interviews. Data analysis was done using a building explanation strategy where the researcher tried to explain the case by making a statement related to the phenomenon studied. The results illustrated the process of environmental communication on waste management in the waste bank community between its supporting stakeholders, brought together three interest actors, namely, the government (Environmental Office), collectors, and waste bank community. They formed a convergent communication model of mutual understanding and interdependencies that position the waste bank as a public issue in waste management.
\end{abstract}

Keywords: waste bank, environmental communications, waste management.

\begin{abstract}
Abstrak. Penelitian ini bertujuan untuk menggambarkan komunikasi lingkungan pengelolaan sampah pada bank sampah di antara pemangku kepentingan di Kota Tangerang Selatan. Penelitian ini menggunakan pendekatan deskriptif kualitatif dengan perolehan data melalui observasi dan wawancara mendalam. Analisis data dilakukan dengan strategi explanation buildings, di mana peneliti mencoba mengonstruksi penjelasan tentang kasus dengan membuat pernyataan terkait fenomena yang diteliti. Hasil penelitian menggambarkan bahwa proses komunikasi lingkungan pada pengelolaan sampah di komunitas bank sampah antara pemangku kepentingan pendukungnya mempertemukan tiga kepentingan yaitu, pemerintah (Dinas Lingkungan Hidup), pengepul, dan komunitas bank sampah. Ketiga pemangku kepentingan tersebut akhirnya membentuk model komunikasi konvergen saling pengertian dan saling ketergantungan yang memosisikan bank sampah sebagai isu publik dalam pengelolaan sampah.
\end{abstract}

Kata kunci: bank sampah, komunikasi lingkungan, pengelolaan sampah.

\section{PENDAHULUAN}

Kota Tangerang Selatan (Tangsel) memiliki permasalahan yang serius terkait dengan tempat pembuangan sampah akhir (TPA). Volume sampah yang dihasilkan masyarakat Tangsel dari data per bulan Ferbuari 2019 telah mencapai 970,49 ton/hari dan hanya sebesar 367 ton/hari sampah yang dapat terlayani oleh Dinas Lingkungan Hidup Tangerang Selatan (DLH Tangsel) sampai terangkut ke TPA (DLH Tangsel, 2020). Pada tanggal 22 Juni 2020, TPA Cipeucang yang dikelola oleh DLH Tangsel yang terletak di Kecamatan Serpong, Tangsel jebol dan timbunan sampah longsor masuk ke sungai 
Cisadane. Lokasi TPA Cipeucang tepat berada di sempadan sungai Cisadene dan berjarak kurang lebih 50 meter dari permukiman warga (Haryanti, 2020). Berdasarkan tinjauan Balai Besar Wilayah Sungai (BBWS) Ciliwung Cisadane, Direktorat Jendral Sumber Daya Air Kementrian Perkerjaan Umum dan Perumahan Rakyat, hal ini terjadi karena sheetpile tidak mampu menahan beban lateral dari tumpukan sampah sehingga sheetpile tersebut roboh sepanjang \pm 60 meter dan panjang kerusakan \pm 100 meter, terjadi gerusan di sekitar sheetpile karena longsor yang disebabkan terjadinya hujan lebat sebelumnya (BBWS Ciliwung Cisadane, 2020).

Berdasarkan Peraturan Menteri Lingkungan Hidup Nomor 13 tahun 2012 pasal 1 (2) yang berbunyi: "Bank sampah adalah tempat pemilahan dan pengumpulan sampah yang dapat didaur ulang dan/atau diguna ulang yang memiliki nilai ekonomi”. Dalam pengelolaan sampah ada dua cara yang telah dilakukan, yaitu dengan dibentuknya Tempat Pembuangan Sementara (TPS) ditambah adanya kegiatan 3R (Reduce, Reuse, Recycle) dan program bank sampah. Perbedaannya adalah bila program TPS dan 3R merupakan program strategis Pemerintah Kota Tangerang Selatan yang dianggarkan secara penuh, bank sampah merupakan program yang dapat memancing partisipasi dan pemberdayaan masyarakat. Program bank sampah di lingkungan Kota Tangerang Selatan sudah dimulai sejak tahun 2012. Berdasarkan data dari DLH Tangsel per tanggal 21 April 2019, sudah terbentuk 230 bank sampah. Jumlah nasabah bank sampah se-Tangerang Selatan sebanyak 7.910 orang. Namun, sejak digerakkan pada tahun 2012, bank sampah yang aktif melaporkan hasil timbangan dan menabung sampah setiap bulannya hanya sebanyak $50 \%$.

Sejumlah 230 bank sampah tersebut dipilih menjadi objek penelitian ini yang dimulai sejak bulan April 2019 hingga Desember 2019. Hasil pengamatan menunjukkan partisipasi cenderung diawali oleh partisipasi masyarakat. Tokoh masyarakat tersebut misalnya Benny Harkamto yang menginisiasi pembentukan dua bank sampah pada tahun 2010 di
Kecamatan Ciputat. Pada tahun 2012 lembaga sosial Yayasan Melati Bersih membentuk bank sampah secara berjejaring yang menyebar di tujuh kecamatan, dan sampai tahun 2014 sudah terbentuk 73 bank sampah. Selanjutnya pada tahun 2014 Pemerintah Kota Tangerang Selatan menargetkan membangun di setiap Rukun Warga (RW) minimal satu bank sampah (satu RW, satu bank sampah), yang jumlah totalnya 735 RW (Kabartangsel.com, 2014). Sosisalisasi dan gerakan diawali pada forum-forum yang terselenggara di masyarakat seperti Pembinaan Kesejahteraan Keluarga (PKK), Pos Layanan Terpadu (Posyandu), lembaga keagamaan seperti majelis taklim dan gereja, Karang Taruna, forum pertemuan Rukun Tetangga (RT) dan Rukun Warga (RW).

Secara legal formal, kepengurusan setiap bank sampah yang terbentuk akan disahkan dengan surat keputusan (SK) yang dikeluarkan masing-masing kelurahan. Sejak tahun 2012 s.d 2019 baru terbentuk 230 bank sampah atau $31,29 \%$ dari target, dan berdasarkan data di bulan Maret 2019 hanya 115 bank sampah $(50 \%)$ yang aktif melaporkan hasil penimbangan setiap bulannya (DLH Tangsel, 2019). Jadi, masih kekurangan 505 bank sampah di Kota Tangerang Selatan. Keberadaan bank sampah masih belum diterima sepenuhnya oleh masyarakat dengan berbagai faktor seperti kesibukan atau stigma negatif yang menganggap bank sampah seperti pekerjaan memulung. Ada juga gesekan dengan lembaga lain yang berbeda pandangan mengenai penanganan sampah seperti program Rumah Minim Sampah (RMS) yang justru bertolak belakang dengan bank sampah yang berupaya agar rumah tangga tidak menghasilkan sampah terutama sampah plastik.

Masalah yang muncul dari proses program bank sampah adalah apakah eksistensi bank sampah mampu mengurangi timbunan di TPA Cipeucang yang sudah penuh dan menggunung. Ini disebabkan partisipasi masyarakat yang masih jauh perbandingannya dengan jumlah penduduk di Tangerang Selatan. Nasabah bank sampah hanya meliputi $0,74 \%$ dari jumlah penduduk Tangerang Selatan (12.288 nasabah) (DLH Tangsel, 2020). Penelitian yang dilakukan 
Aminudin dan Manggolo (2017) menunjukkan bahwa program bank sampah dan tingkat kepuasan tidak berpengaruh terhadap pendapatan keluarga nasabah bank sampah. Program bank sampah dengan tingkat pendapatan keluarga nasabah bank sampah di Kecamatan Ciputat Timur memiliki korelasi sangat lemah $(0.001 \%)$ dan tingkat kepuasan nasabah bank sampah dengan tingkat pendapatan keluarga nasabah bank sampah juga lemah $(0,014 \%)$. Selanjutnya, masalah keberlanjutan program dan regenerasi pengurus bank sampah yang didominasi oleh penduduk usia 31- 40 tahun (37\%), 40 - 50 tahun $(38 \%),>50$ tahun $(15 \%)$, sementara usia 17 - 30 tahun hanya sebesar $10 \%$ (hasil survei prapenelitian bulan April 2019). Angka tersebut menggambarkan masih sedikitnya generasi muda yang terlibat pada program bank sampah.

Eksistensi bank sampah tidak terlepas dari relasi yang berkelanjutan di antara pemangku kepentingan yang menopangnya. Ada tiga aktor penting yang selalu berinteraksi, yaitu DLH Tangsel sebagai pelaksana regulasi, partisipasi masyarakat yang membentuk komunitas bank sampah, dan pelapak atau pengepul yang menjadi penyalur penjualan hasil penimbangan bank sampah di mana uang hasil penimbangan sampah dicatat oleh setiap nasabah sebagai tabungan. Terdapat hubungan triadik yang terjadi dalam konteks komunikasi lingkungan, karena relasi yang terjadi merupakan isu yang terkait masalah lingkungan, yaitu pengelolaan sampah di Kota Tangerang Selatan. Relasi yang terjadi tidak terlepas dari motif dan kepentingan yang berbeda dalam proses komunikasi yang berlangsung, sehingga terkadang terjadi permasalahan yang membutuhkan jalan keluar agar program bank sampah dapat berjalan dan berkelanjutan.

Penelitian ini bertujuan untuk menggambarkan komunikasi lingkungan pengelolaan sampah pada bank sampah yang terjadi di antara pemangku kepentingan di Kota Tangerang Selatan, yang meliputi: 1) peran pemangku kepentingan pendukung (tema lingkungan sebagai sumber swasta/pelapak, lingkungan sebagai objek pemerintah kota (DLH), dan lingkungan sebagai spirit komunitas bank sampah; 2) membuat model komunikasi konvergensi di antara pemangku kepentingan pada program bank sampah di Kota Tangerang Selatan.

\section{LANDASAN KONSEP}

\section{Komunikasi Lingkungan}

Teori komunikasi lingkungan tidak terlalu teoretis dan lebih rinci ditemukan dalam teori M. Jimmie Killingsworth dan teori transaksional Jaqueline S. Palmer tentang retorika. Teori ini menguji cara-cara kelompok berkomunikasi satu sama lain. Killingsworth dan Palmer telah membuat representasi grafis dari semua komunitas wacana lingkungan dan bagaimana mereka berinteraksi dan berkomunikasi satu sama lain. Teori ini mudah dipahami dan sangat berguna karena gambargambar konkret yang diperoleh dari representasi grafis (Killingsworth dan Palmer, 2012). Lebih dari satu abad pandangan tentang alam dan lingkungan tidak begitu kompleks seperti sekarang ini. Killingsworth \& Palmer (2012) memaparkan perspektif yang lebih lama terkait masalah ini. Gambar 1 menampilkan rangkaian perspektif terhadap dunia alami seabad yang lalu.

Tiga perspektif tentang alam yang digambarkan dalam bentuk komunitas wacana yaitu: alam sebagai objek, alam sebagai sumber daya, dan alam sebagai spirit yang ditampilkan dalam sebuah kontinum lurus. Mereka yang melihat alam sebagai objek yang akan dipelajari adalah sains tradisional (Killingsworth \& Palmer, 2012). Maka sains tradisional adalah faham antroposentrisme yang meletakkan posisi manusia sebagai sentral, sementara alam adalah objeknya. Sains tradisional memiliki cara pandang yang berlawanan tentang alam dengan deep ecology (ekologi yang mendalam) yang ditunjukkan di ujung kontinum. Namun, deep ecology sejalan dengan ekosentrisme, sebuah pandangan bahwa semua yang ada di alam baik biotik, abiotik, dan manusia berada dalam sistem yang saling ketergantungan. 


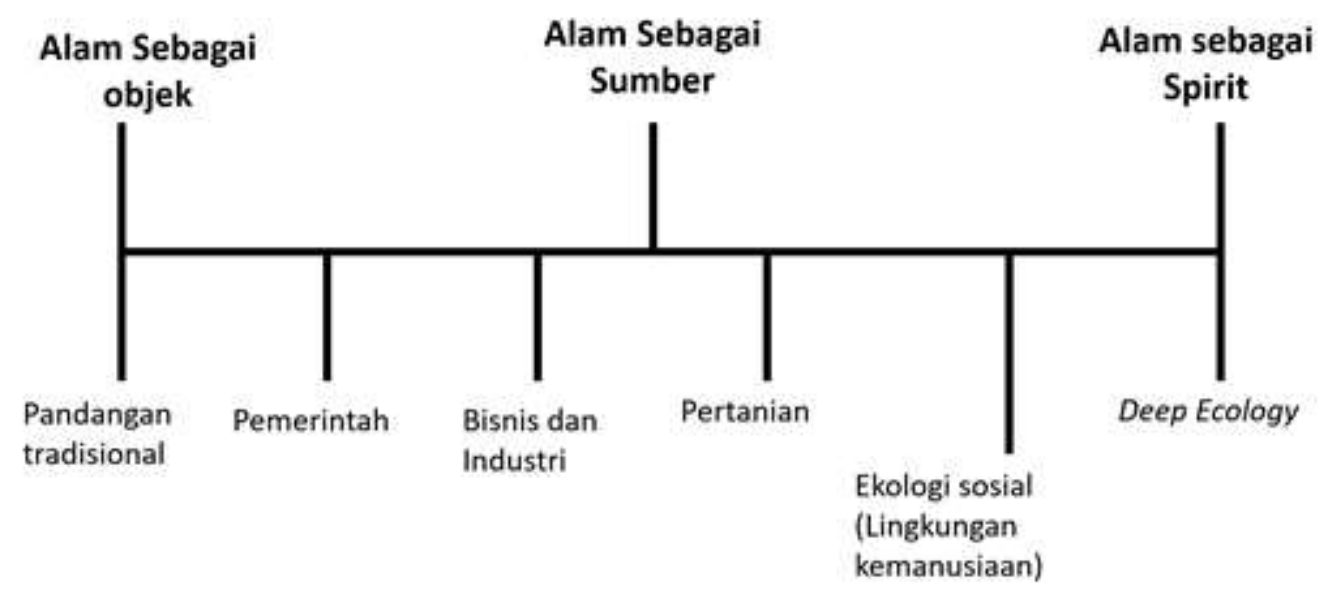

Sumber: Killingsworth \& Palmer (2012)

\section{Gambar 1. Kontinum pada Perspektif Lingkungan}

Killingsworth \& Palmer (2012) menyarankan bahwa setiap orang dapat mengalami semua perspektif tentang alam ini pada satu waktu atau waktu yang lain, tetapi untuk setiap orang satu perspektif akan selalu tampak mendominasi pandangan yang lain. Bisnis dan industri memandang alam sebagai sumber daya yang akan digunakan untuk kepentingan ekonomis dan mendapatkan profit. Melihat alam sebagai sumber daya tidak berarti bahwa seseorang tidak dapat melihat alam sebagai objek atau spirit, tetapi akhirnya satu pandangan akan lebih kuat dari yang lain.

Pada kontinum, pemerintah berada di antara sains tradisional, bisnis, dan industri. Penggambaran ini menunjukkan bahwa pemerintah tidak bisa sepenuhnya berada di pihak sains tradisional atau benar-benar di sisi bisnis dan industri. Jika instansi pemerintah berpihak pada sains tradisional atau bisnis dan industri, itu pasti tidak strategis bagi masa depan pemerintah. Gambar 2, menunjukkan perbedaan dramatis dalam komunitas wacana lingkungan; perbedaan persepsi antara kelompok dan keseluruhan polaritas antara alam sebagai objek dan alam sebagai spirit. Komunitas wacana yang berbeda tidak didorong untuk berkomunikasi satu sama lain ketika ditampilkan dalam sebuah kontinum (McManus, 1996).

Ketika "revolusi lingkungan" semakin populer selama abad ke-20, kontinum perspektif ini telah berubah. Killingsworth \& Palmer (2012) menciptakan konfigurasi kedua di mana semua komunitas wacana memiliki akses satu sama lain di dalam masyarakat. Dalam perspektif yang lebih mutakhir ini, individu dan kelompok dapat berkomunikasi dan berusaha bergerak maju untuk membuka pikiran mereka terhadap nilai-nilai dan ide-ide lingkungan dari kelompok-kelompok lain yang berfungsi di masyarakat.

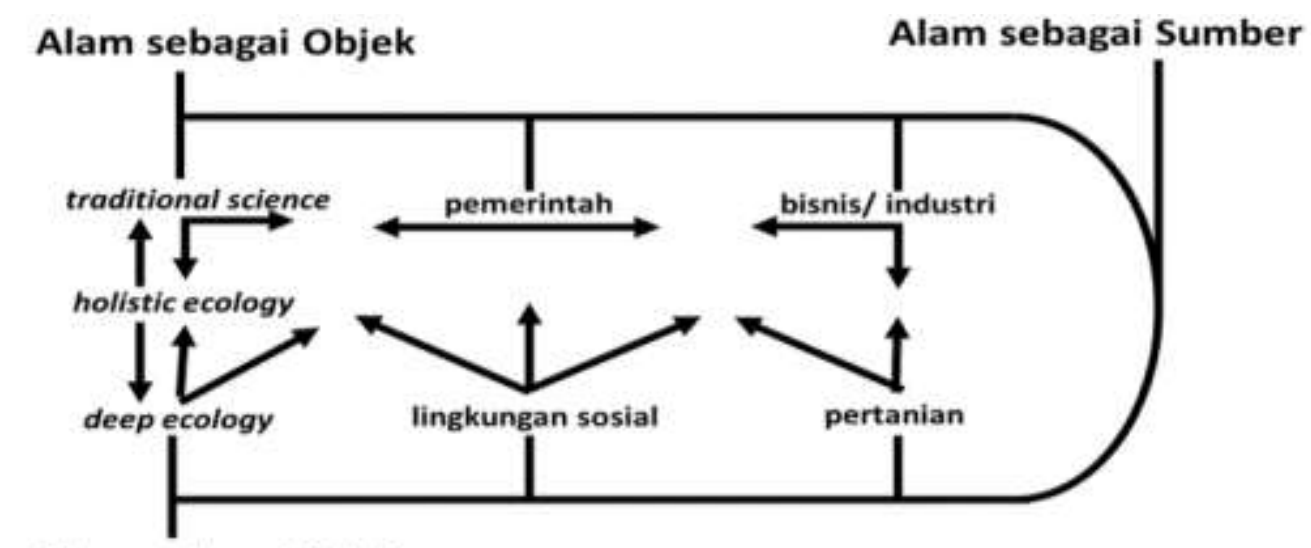

Alam sebagai Spirit

Sumber: Killingsworth \& Palmer (2012)

Gambar 2. Konfigurasi Perspektif Tapal Kuda. 
Killingsworth \& Palmer (2012) telah membuat konfigurasi yang mencakup semua komunitas wacana lingkungan fungsional dan sarana yang digunakan untuk berinteraksi dan berkomunikasi. Gambar 2 adalah konfigurasi yang dianalogikan sebagai perspektif tapal kuda karena bentuknya seperti lengkungan tapal kuda. Tapal kuda adalah kontinum perspektif terkait lingkungan bila di lingkungan dan terjadi pertemuan dan persinggungan di antara kelompok wacana, di mana adanya relasi yang menggambarkan hubungan kerja sama dan potensi relasi ketegangan yang muncul karena perbedaan kepentingan. Konfigurasi tapal kuda adalah representasi yang sangat baik dari berbagai wacana komunitas dalam komunikasi lingkungan. Diagram ini disiapkan untuk menunjukkan interaksi antara industri, pemerintah, sains tradisional, ekologi sosial (manusia), dan deep ecology, yaitu sebuah cara pandang dan gaya hidup yang menyelaraskan diri dengan alam. Manusia akan merawat atau menjaga lingkungan seperti mereka menjaga dan merawat rumah tangganya. Sehingga manusia tidak lagi dilihat dalam suatu kesatuan yang terpisah, tetapi merupakan satu kesatuan dengan alam (Naess, 1973). Dapat mulai dilihat perspektif lingkungan secara holistik dan bukan sebagai tiga kelompok individu dengan tiga sistem nilai yang berbeda. Dengan menggunakan penggambaran Killingsworth \& Palmer (2012), dapat dipandang masyarakat sebagai sistem besar dengan berbagai nilai, metode, dan alasan untuk berkomunikasi.

Diagram perspektif pada Gambar 2 menggambarkan empat konsep: hegemoni, pertentangan, ketegangan, dan arah banding. Tiga komunitas wacana di atas sumbu-sumbu sains tradisional, pemerintah, dan bisnis/industri adalah kelompok-kelompok yang memiliki kekuatan paling besar dan dukungan atau hegemoni paling umum. Tiga komunitas wacana di poros bawah ekologi yang mendalam (deep ecology), ekologi sosial (manusia), dan pertanian adalah komunitas dengan kekuatan dan dukungan publik terkecil. Mereka dapat mengancam kelompokkelompok kuat di poros atas karena mereka tidak memiliki kekuatan dan juga tidak akan rugi. Di masa yang lalu para pemimpin yang paling kuat di atas (yaitu bisnis/industri) tidak memiliki nilai lingkungan yang kuat (Killingsworth \& Palmer, 2012). Namun sekarang tampaknya ada pergeseran dalam sikap. Secara teoretis, perspektif tapal kuda ini cukup menjanjikan, tetapi dapat membantu dalam hal keefektifan. Killingsworth dan Palmer (2012) berpendapat bahwa agar perubahan dalam sikap ketertarikan terhadap lingkungan melalui komunitas-komunitas, upaya komunikasi konvergen (memusat) harus dibangun di antara kelompok-kelompok wacana terkait dengan pola diskursif. Perubahan ini akan bergantung pada komunikasi yang efektif dan cara-cara baru dalam berbisnis.

Anak panah di tapal kuda mewakili empat jenis interaksi di antara komunitas wacana ditampilkan pada diagram tapal kuda. Interaksi ini terdiri dari hegemoni, pertentangan, ketegangan, dan penolakan. Panah menunjuk pada relasi di mana akan berpotensi adanya pertentangan karena perbedaan kepentingan. Panah yang menunjuk satu sama lain mewakili ketegangan. Panah menunjuk keluar mewakili oposisi. Konsep pertama: hegemoni, mudah dimengerti dengan melihat perebutan kekuasaan antara pemerintah, bisnis/industri, dan sains tradisional. Ketiga komunitas ini berjuang dengan nilai-nilai yang berbeda dan kebutuhan moneter yang berbeda; semua komunitas berusaha menyatukan kekuatan. Konsep kedua: oposisi, diwakili pada perspektif tapal kuda oleh jarak secara vertikal dan horizontal dari semua komunitas wacana satu sama lain. Pemerintah terletak di pusat konfigurasi tapal kuda karena itu adalah objek banding dari semua komunitas pada Gambar 2. Konsep ketiga: ketegangan, juga diwakili oleh jarak vertikal dan horizontal antara komunitas wacana lingkungan. Tidak hanya ada oposisi di antara kelompok-kelompok tetapi juga ketegangan. Kelompok-kelompok yang paling dekat satu sama lain dan memiliki banyak pandangan lingkungan yang sama juga dapat memiliki ketegangan besar di antara mereka. Konsep keempat adalah arah banding; konsep ini juga diwakili oleh panah di tapal kuda. Tanda panah menunjukkan arah retorika banding yang dicapai setiap komunitas wacana pada saat dibutuhkan. Pemerintah menerima 
paling banyak permohonan dari semua komunitas. Panah menunjukkan di mana ikatan antarindividu/institusi dapat dibuat atau dirusak tergantung pada aksi politik yang terjadi (Killingsworth \& Palmer, 2012).

Jika regulasi atau undang-undang disahkan, tidak banyak yang dapat dilakukan kelompok yang lebih kecil dan kekuatannya tidak besar. Ada ketegangan dan pertentangan besar antara pemerintah dan bisnis/industri. Pemerintah selalu menjadi target pengajuan moneter untuk semua komunitas pada diagram tapal kuda. Pemerintah memiliki kekuatan dan uang, oleh karena itu pemerintah memegang kendali (Killingsworth \& Palmer, 2012). Relasi di antara stakeholders menurut Killingsworth dan Palmer (2012) bahwa adanya unsur hegemoni, pertentangan, dan ketegangan yang berpotensi menjadi hambatan sesuai data prapenelitian ditemukan dari 230 bank sampah, ditunjukkan dengan hanya 115 bank sampah atau 50\% yang aktif melaporkan hasil penimbangan pada setiap bulan. Keberlanjutan program bank sampah diasumsikan karena proses komunitas bank sampah dengan kondisi lingkungan tempat tinggal, kondisi status sosial, dan budaya masyarakat menyebabkan ada beberapa tipe bank sampah yang berkembang sesuai dengan kondisi yang membentuknya.

\section{Model Komunikasi Konvergensi}

Paradigma komunikasi linear digagas oleh para pendiri ilmu komunikasi seperti Harold D. Lasswell dalam skema "siapa mengatakan apa? melalui saluran apa? kepada siapa? apa efeknya?". Terdapat pula model komunikasi yang dikembangkan oleh Shannon dan Weaver, Wilbur Schramm, Westley dan Mclean, dan David K. Berlo dengan model Source-Message-Channel-Receiver (SMCR). Model komunikasi linear menggambarkan alur komunikasi yang satu arah antara pengirim dan penerima pesan. Sehingga model linear lebih menggambarkan proses komunikasi yang bersifat top-down atau dari atas ke bawah. Komunikasi model linear yang sangat mekanis tidak cocok bila diterapkan pada komunikasi lingkungan, karena isu lingkungan hidup dan kelestariannya hanya dapat dilakukan dengan adanya timbal balik (bottom-up), bersinergi dan kolaborasi di antara semua stakeholders (Flor, 2004).

Kincaid (1979) memaparkan beberapa kesalahan (bias) pada model linear, yaitu: 1) Pandangan yang melihat komunikasi sebagai suatu proses linear (satu arah), dan sifatnya vertikal, sehingga tidak melihat komunikasinya sebagai suatu proses yang berputar sebagai lingkaran, dua arah, dan berlangsung dari waktu ke waktu; 2) Sumber jadi dominan di mana khalayak atau penerima sangat tergantung (dependency) pada sumber, dan tidak melihat proses komunikasi yang pada dasarnya dibangun atas hubungan saling ketergantungan (interdependency); 3) Ada kecenderungan melihat objek komunikasi (penerima) berada dalam ruang hampa dan terisolasi sumber; 4) Pesan dilihat sebagai unsur tersendiri dengan penekanan pada isi, sehingga kadang tidak memperhatikan kondisi dan waktu di mana pesan disampaikan; 5) Ada kecenderungan melihat tujuan utama komunikasi adalah memersuasi, dan bukan saling pengertian, kesepakatan, dan tindakan kolektif; 6) Ada kecenderungan melihat proses komunikasi terkonsentrasi pada efek psikologis daripada efek sosial dan hubungan antarindividu; 7) Sebuah kepercayaan yang dibangun dengan perspektif komunikasi sebagai proses satu arah yang mekanis, dan tidak melihat komunikasi sebagai sistem informasi manusia secara sibernetika yang berlangsung setiap saat dan di mana saja (Flor \& Cangara, 2018).

Model komunikasi linear bila diimplementasikan pada komunikasi lingkungan seperti pada penelitian mengenai pengelolaan sampah (bank sampah) akan menempatkan pemerintah sebagai sumber informasi yang menyebabkan ketergantungan masyarakat. Sementara kunci keberhasilan penanganan sampah harus dimulai dari sumbernya, yaitu sampah rumah tangga, sehingga masyarakat pun harus dapat menjadi komunikator dengan posisi yang setara dengan pemerintah, sehingga tercipta hubungan yang saling ketergantungan. 


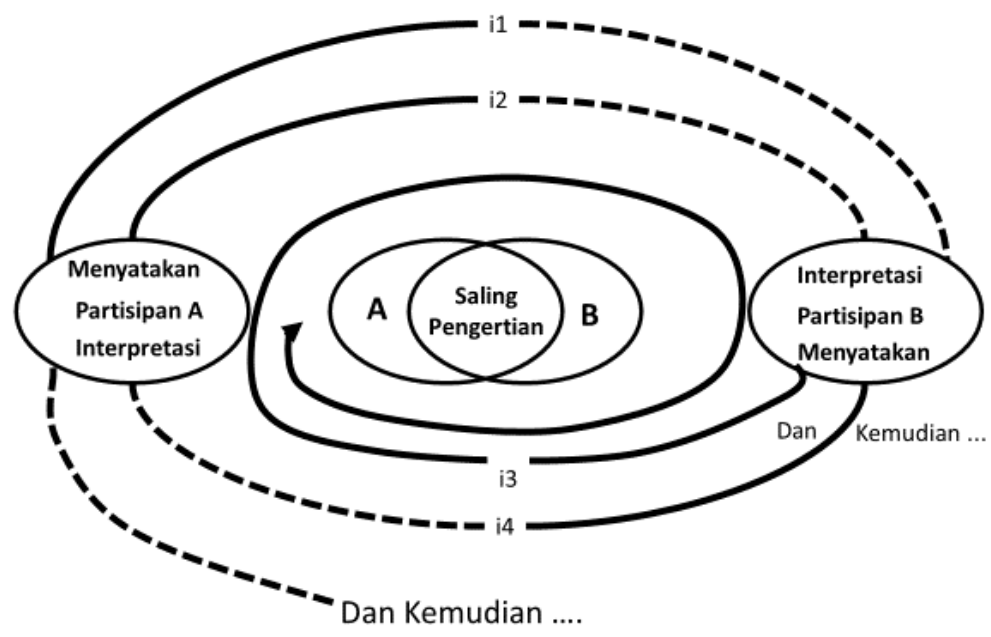

Sumber: Kincaid (1979); Flor \& Cangara (2018)

\section{Gambar 3. Model Komunikasi Konvergen}

Model pada Gambar 3 (Kincaid, 1979), menjelaskan bahwa komunikasi selalu dimulai dengan "dan kemudian..." untuk mengingatkan bahwa sesuatu telah terjadi sebelum dimulai berkomunikasi. Partisipan A mungkin tidak menyadari peristiwa/masalah sebelum A berbagi informasi (i.1) dengan partisipan B. Partisipan B harus berusaha memahami dan kemudian menginterpretasikan informasi yang A sampaikan sesuai kerangka pikirnya, lalu B menanggapi dan menciptakan informasi (i.2) untuk berbagi dengan A. Selanjutnya A menafsirkan informasi baru tersebut (i.3) ke dalam topik yang sama. Partisipan B menafsirkan informasi itu, lalu mereka melanjutkan pembicaraan tentang topik tersebut (i.4...n) sampai salah satu atau keduanya menjadi puas bahwa mereka telah mencapai saling pengertian satu sama lain tentang masalah yang dibicarakan itu. Setiap partisipan menafsirkan informasi yang mereka miliki dan berusaha memahami dan menemukan cara yang lebih baik untuk mengekspresikan/menyatakannya. Dengan demikian, tidak ada panah yang mengarah "ke...dan dari ..." setiap informasi. Informasi menjadi milik bersama oleh kedua partisipan. Model ini menekankan bahwa tujuan utama atau fungsi dari proses komunikasi adalah saling pengertian (Kincaid, 1979).

Komunikasi tidak bisa dipandang hanya faktor pendukung dalam penanganan masalah lingkungan, melainkan harus menjadi bagian integral di dalamnya. Tanpa menempatkan komunikasi sebagai komponen penting, maka usaha pengelolaan lingkungan secara keseluruhan akan menghadapi banyak masalah. Komunikasi dapat melakukan pendekatan budaya yang tepat dan memungkinkan menjadi penentu dinamika sosial. Komunikasi lingkungan dengan model konvergensi tidak selalu menjadi sumber oriented (source/communicator) dan media sentris, tapi harus bisa mendorong terjadinya partisipasi yang lebih besar dari penerima (receiver). Program komunikasi lingkungan harus mengaktifkan dan memberdayakan khalayak agar tidak pasif, tetapi bisa menjadi sumber informasi yang aktif setiap saat (Flor \& Cangara, 2018).

Komunikasi konvergensi akan melihat secara holistik, yaitu menghargai totalitas dan dinamika permasalahan lingkungan. Penekanannya pada komunikasi yang sirkular dan transaksional yang membuat posisi sebagai komunikator saling bergantian di antara mitra yang terlibat dalam masalah lingkungan khususnya terkait penelitian ini adalah masalah pengelolaan sampah melalui bank sampah. Hal ini sangat relevan dengan kegiatan ekonomi sirkular yang tentunya melibatkan stakeholder mulai dari produsen, konsumen, komunitas bank sampah, pengepul, industri daur ulang, akademisi, aktivis lingkungan, dan juga pemerintah daerah. Semua stakeholder dalam posisi di mata rantai lingkaran komunikasi yang melingkar dalam 
aktivitas ekonomi sirkular dan peran masingmasing berfungsi saling terintegrasi, sinergi, dan kolaborasi agar lingkaran keberlanjutan terus berputar seperti roda.

\section{METODE PENELITIAN}

Penelitian ini menggunakan paradigma konstruktivis, dengan pendekatan kualitatif yang dilakukan dengan mengasumsikan bahwa individu membangun makna secara subjektif dari pengalamannya dan interaksi dengan lingkungannya. Pembentukan makna terus dinegosiasi oleh individu yang memiliki perbedaan sosial dan historis yang beroperasi dalam setiap kehidupan individu (Creswell, 2009).

Lokasi penelitian adalah di Kota Tangerang Selatan yang terletak di bagian Timur Provinsi Banten. Pengumpulan data kualitatif pada penelitan dikelompokkan menjadi empat tipe: 1) Pengamatan (observasi) terhadap partisipan dan nonpartisipan; 2) Wawancara tertutup dan terbuka; 3) Dokumen pribadi dan public; dan 4) Bahan audiovisual mencakup foto, video, rekaman audio. Dengan adanya data internet termasuk ruang obrolan (chat room) (Creswell dan Poth, 2018), penelitian ini juga mengamati obrolan/percakapan daring yang terjadi di grup
WhatsApp yang sudah digunakan sebagai forum komunikasi dan koordinasi komunitas bank sampah dan stakeholder lainnya.

Informasi juga digali dari berbagai sumber data atau unit analisis dengan teknik purposive dan snowball sampling, yaitu: 1) Informan (narasumber) secara purposive sampling, yaitu meliputi semua stakeholder yang terkait dengan program bank sampah yang merupakan informan kunci, yaitu: Ahmad Rivai (Kepala Seksi Kerjasama dan Pemberdayaan Masyarakat DLH Tangsel); H. Wakidi (Ketua Perkumpulan Bank sampah Tangsel, PERBAS); Mardiono (Sekertaris PERBAS); Turmanto dan Posma (Pengepul); Saronto, Sukendro (Ketua Rukun Warga), Sri Fathonah, Andi (Ketua Rukun Tetangga); Siti Hajar, Kartini, Ismuniati (pendamping dan kordinator Kecamatan bank sampah yang ditunjuk DLH Tangsel); Riska Djoepri, Irma Yunita (Pengurus bank sampah), Endang, Suyatmi, Sulthan (Nasabah bank sampah); dan selanjutnya informan terus bergulir mengembang (snowball sampling) hingga berjumlah 58 informan. 2) Arsip dan dokumen, yaitu catatan/data kegiatan, data jumlah nasabah, dan dokumen lainnya yang mendukung; 3) Catatan lapangan hasil observasi di tempat yang terkait peristiwa dan kegiatan.

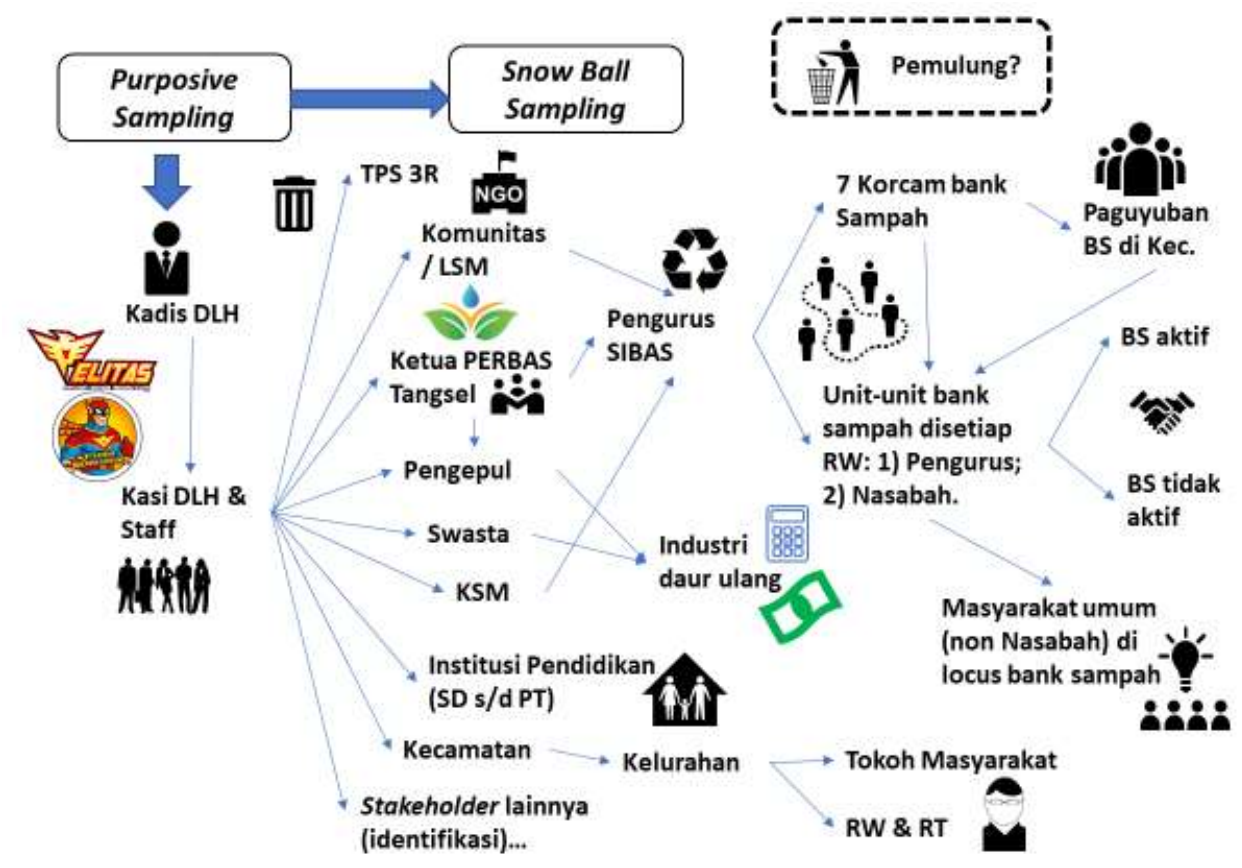

Sumber: Olah data penelitian (2019)

Gambar 4. Peta Unit Analisis Penelitian. 
Teknik analisis data dalam penelitian ini sudah dilakukan dengan menggunakan strategi analisis explanation buildings, yaitu peneliti mencoba untuk mengonstruksi penjelasan tentang kasus dengan membuat pernyataan terkait fenomena yang diteliti (Wimmer dan Dominick, 2011). Data yang telah dikumpulkan lalu dianalisis dan dikelompokkan untuk melakukan kategorisasi atau pemilahan menurut domain tertentu. Hasil dari pengelompokkan akan dianalisis dengan membandingkan teori-teori yang telah disusun pada tinjauan pustaka, disebut sebagai logika penjodohan pola atau diistilahkan analysis time series (Yin, 2012). Hasil penelitian berupa hasil wawancara dan dokumentasi lainnya disajikan secara sistematis dan dihubungkan dengan teori yang relevan serta membuat pernyataan (argumentasi) hasil penelitian sampai tahap simpulan dan saran.

\section{HASIL PENELITIAN DAN PEMBAHASAN}

Komunikasi lingkungan adalah sebuah kajian yang membahas mengenai interaksi manusia dengan alam lingkungan. Implementasi komunikasi lingkungan sebagai tindakan simbolik karena peristiwa atau fakta yang terjadi di alam merupakan pesan berupa simbol terkait dampak dari aktivitas manusia, termasuk masalah sampah yang sudah sangat mencemari lingkungan baik di daratan dan lautan. Komunikasi menjadi tindakan simbolik yang memediasi kepercayaan, sikap, dan perilaku manusia terhadap lingkungan sehingga berdasarkan model komunikasi lingkungan (Cox dan Pezzullo, 2015) harus ada ruang publik agar terjadi proses percakapan, diskursus, dan pelibatan orang lain atau kelompok dan lembaga yang terkait permasalahan sampah. Maka ruang publik tersebut termediasi melalui program bank sampah dengan terbentuknya komunitas bank sampah dari unsur masyarakat.

Konstruksi bank sampah didasari beberapa regulasi yang telah diberlakukan oleh pemerintah, yaitu dengan terbitnya: 1) Undang-Undang Republik Indonesia Nomor 18 Tahun 2008 Tentang Pengelolaan Sampah; 2) Peraturan Pemerintah Nomor 81 Tahun
2012 Tentang Pengelolaan Sampah Rumah Tangga dan Sampah Sejenis Sampah Rumah Tangga; 3) Peraturan Menteri Lingkungan Hidup Nomor 13 Tahun 2012 Tentang Pedoman Pelaksanaan Reduce, Reuse dan Recycle melalui Bank Sampah; 4) Turunan berupa Peraturan Daerah Kota Tangerang Selatan Nomor 3 Tahun 2013 tentang Pengelolaan Sampah.

Penelitian ini telah memetakan proses komunikasi lingkungan pada program bank sampah yang melibatkan tiga stakeholder utama, yaitu Pemerintah Kota dalam hal ini adalah Dinas Lingkungan Hidup (DLH) Tangerang Selatan, komunitas bank sampah, dan para pengepul dan pihak pendukung lainnya dalam uraian unsur-unsur komunikasi yang telah terjadi seperti pada Tabel 1 .

Komunikasi lingkungan memiliki karakteristik yang khas karena permasalahan lingkungan hidup adalah masalah yang sistemik, sehingga pasti akan menjelaskan relasi dan interaksi di antara aktor/komunikator/komunikan yang terlibat (stakeholder) dalam hubungan saling ketergantungan (interdependensi). Model komunikasi lingkungan yang diperkenalkan oleh Killingsworth dan Palmer (2012) menggambarkan adanya tiga konfigurasi dari komunitas wacana yang saling terhubung dengan garis-garis relasi dalam ketegangan kepentingan berdasarkan wacananya, yaitu komunitas yang memandang alam sebagai objek (A), alam sebagai sumber (B), dan alam sebagai spirit (C). Komunikasi menjadi suatu cara untuk mengelola ketegangan tersebut agar menjadi tindakan yang sinergi, kolaboratif dalam mengatasi masalah lingkungan dalam hal ini masalah sampah dengan program bank sampah. Seperti yang dipaparkan dalam teori komunikasi lingkungan dari Killingsworth and Palmer (2012), bahwa akan ada ketegangan kepentingan antara stakeholder terkait program bank sampah, yaitu pemerintah dalam hal ini DLH Tangsel, komunitas bank sampah, dan pengepul. Komunikasi konvergen, di mana perlu selalu kembali kepada tahap saling pengertian (mutual understanding), karena kerap muncul perbedaan kepentingan seperti masalah harga, keterlambatan karena ketidakseimbangan jumlah pengepul dengan bertumbuhnya bank-bank sampah. 


\section{Tabel 1}

Komponen-Komponen Komunikasi Lingkungan pada Program Bank Sampah

\section{Komponen-Komponnen Komunikasi Bank Sampah \\ Source: Pengirim/ pembuat pesan.}

Encoding: Pembentukan pesan (simbol)

Message: Informasi, simbol, verbal/nonverbal, sesuatu yang disampaikan/dikirim/ditujukan.

Channel: Saluran yang digunakan

Decoding: Menerjemahkan pesan (interpretasi/mengartikan, memecahkan, membuka, memaknai, memahami, etc.

Receiver: Penerima pesan (simbol).

Effect: Dampak sikap, tingkah laku (kognitif, afektif, konatif/psikomotorik).

Context: Situasi, kondisi, lingkungan

Noise: Gangguan dan hambatan

Feedback: Umpan balik, reaksi yang dikembalikan

\section{Keterangan dan Implementasi}

Pemerintah pusat, provinsi, kota, tokoh masyarakat, kelompok swadaya masyarakat, swasta (pengepul), akademisi, LSM, masyarakat umum.

Isu upaya pengelolaan sampah dengan membentuk bank sampah sebagai social engineering.

Bank sampah sebagai pesan komunikasi lingkungan: mengubah sampah menjadi bernilai ekonomis dan pengembangan masyarakat.

Antarpribadi, kelompok, organisasi, media massa, media sosial, grup WhatsApp (WAG).

Sebagai solusi lingkungan dengan cara Pengembangan dan partisipasi masyarakat: pengembangan sosial, politik, lingkungan, personal/ spiritual, ekonomi, dan budaya.

Masyarakat (atas, menengah, bawah), swasta, akademik.

Mengerti (sadar), merasakan, bertindak (partisipasi) atau menolak, mengabaikan, atau tidak memahami/ negatif dengan program bank sampah.

Bank sampah ada yang aktif dan tidak, respon berbedabeda sesuai kondisi lingkungannya.

Kendala kurangnya SDM, belum ada pola regenerasi, kejenuhan. berbeda kepentingan dalam pengelolaan sampah, stigma negatif masyarakat.

Terbentuknya kepengurusan, penambahan nasabah bank sampah, dan sebagai wadah edukasi mengenai lingkungan.

Sumber: Olah data penelitian (2019)

Bank sampah adalah sebuah kebijakan berupa komunikasi strategis yang berprinsip kepada tujuan dari pembangunan berkelanjutan (suitainable development), yang menggabungkan kepentingan sosial, ekonomi, dan lingkungan. DLH Tangsel dalam posisi yang statis karena dipayungi regulasi dan anggaran rutin APBD. Kepala Seksi Kerjasama dan Pemberdayaan Masyarakat DLH Tangsel, Ahmad Rivai memaparkan: "Dinas Lingkungan Hidup Tangerang Selatan bisa membuat masyarakat itu semangat ya kita menyiapkan fasilitas timbangan, gantungan timbangan, buku tabungan, spanduk, jadi setiap ada masyarakat mau membuat bank sampah, kita antar secara gratis fasilitas itu. Kemudian memang juga ada keinginan bu Airin Walikota Tangsel itu satu RW satu bank sampah, memang kita sedang meningkatkan itu. Kemudian ada lagi Peraturan Walikota No. 21 Tahun 2019 Tentang Kebijakan dan Strategis Daerah Sampah Rumah Tangga dan Sampah Sejenis Rumah Tangga, nah itu ada di situ di Lampiran 2 memang bank sampah harus bertumbuh terus untuk mengurangi pengurangan yang kedua penanganan sampah. Nah bank sampah ini masuk dalam kategori pengurangan sampah karena pengurangan itu yang full dilakukan oleh masyaakat tanpa ada campur tangan rutin APBD" (Ahmad Rivai, 16/08/2019)

Di sisi lain pengepul memiliki motivasi yang stabil karena alasan profit, seperti yang dipaparkan informan pengepul Turmanto di Tangerang Selatan yang menangani 96 bank sampah di Kota Tangerang Selatan, sebagai berikut: "Manfaat dengan adanya bank sampah beban saya jadi ringan. Maksudnya kalau yang ada di bank sampah kan umumnya barang yang tercampur seperti ember kok tercampur sama beling itu kan ada unsur ketidaksengajaan kalau dari bank sampah karena bukan profesinya mungkin. Tapi kalau yang namanya tukang rongsok gitu kan contoh ini kardus tengah-tengah dikasih air terus cara ngiketnya juga luar biasa yang akhirnya saya 
rugi. Ya intinya kalau di bank sampah kita jarang dibohongi tapi yg namanya curang ya pasti ada aja" (Turmanto, 18/03/2020).

Pengepul sangat merasakan manfaat dengan adanya bank sampah yang terus bertumbuh di Kota Tangerang Selatan, hal ini seperti diuraikan informan, seperti sampah yang sudah terpilah dan bersih, dan juga adanya jadwal pasti pengambilan sampah dan volume yang stabil dari 96 bank sampah yang ditangani oleh pengepul. Informan Turmanto juga membandingkan bila dia mengambil dari tukang rongsok/pemulung yang memiliki potensi tidak jujur.

Sementara posisi komunitas bank sampah masih bisa dikatakan tentatif karena masih mengandalkan jiwa kerelawanan terutama peran pengurus bank sampah sebagai penggerak dan partisipasi masyarakat (nasabah), seperti yang dipaparkan oleh informan Ketua Perkumpulan Bank Sampah Tangsel (PERBAS) H. Wakidi: "Semuanya penggiat bank sampah harus banyak maklum terhadap siapa saja, harus banyak maklum terhadap pejabat, harus banyak maklum terhadap pengepul, harus banyak nasabah, sehingga agar kita terhindar dari masalah yang nanti pada muaranya apabila kita banyak maklum sebetulnya yang akan menjadi korban adalah diri saya sendiri, apabila kita tidak banyak maklum. Segala hal itu harus banyak maklum, segala hal itu harus banyak maklumnya, toleransinya harus tinggi, kalau tidak maka kita nanti yang akan banyak pikiran sendiri, ya, sudah banyak pikiran, kenapa jadi repot kita mikirin orang gitu. Saya sudah gak ada saya hari ini berdebat dengan selesai hari itu, gak ada perpanjangan. Saya semalam diskusi rapat sampai nunjuk muka dan sebagainya, ya selesai. Besok ketemu, makan bareng, gak ada masalah" (H. Wakidi, 28/09/2019).

Berdasarkan kutipan ketiga informan yang mewakili tiga perspektif tema lingkungan yang berbeda merujuk konsep konfigurasi tapal kuda komunikasi lingkungan Killingsworth \& Palmer (2012), pemerintah berada di posisi menjadikan tema lingkungan sebagai objek, yaitu regulator dan fasilitator di mana pemerintah menjadi sentral dalam arus komunikasi yang menggambarkan kondisi hegemoni, ketegangan, pertentangan, dan penolakan dari berbagai pihak seperti pada konfigurasi tapal kuda (Killingsworth \& Palmer, 2012) dikodekan huruf A (objek). Berdasarkan Undang-Undang No. 18 Tahun 2008 tentang Pengelolaan Sampah (UU Pengelolaan Sampah), khususnya Pasal 13 dan Pasal 45 mengamanatkan sampah "wajib" dikelola di sumber timbunannya. Selanjutnya berdasarkan Pasal 8, provinsi menetapkan kebijakan dan strategi dalam pengelolaan sampah sesuai dengan kebijakan pemerintah, dan Pasal 9 menyelenggarakan pengelolaan sampah skala kabupaten/kota sesuai dengan norma, standar, prosedur, dan kriteria yang ditetapkan oleh pemerintah. Pemetaan kewenangan pengelolaan sampah tersebut menunjukkan bahwa sebagian besar kewenangan pengaturan berada pada pemerintah pusat, akan tetapi kewenangan pelaksanaan hampir sepenuhnya berada di daerah.

Pemerintah Kota Tangerang Selatan sebagai regulator dan fasilitator, harus mengambil peran atau inisiatif (top down) dalam menetapkan dan mendukung program bank sampah oleh masyarakat di tingkat kelurahan (Hoesein, 2019). Dari persepektif tema lingkungan sebagai sumber, yaitu pengusaha dalam hal ini pengepul/pelapak memandang sampah sebagai sumber daya yang sangat dibutuhkan karena mengejar kepentingan ekonomis, yaitu keuntungan (profit) dikodekan dengan huruf B (sumber). Akhirnya, posisi bank sampah faktanya merupakan sebuah komunitas yang terbentuk dalam perspektif tema lingkungan (sampah) sebagai spirit, yaitu terdapat proses posisi keterlibatan dalam pengelolaan sampah menjadi sebuah edukasi kepedulian lingkungan, dikodekan huruf C (spirit).

Kondisi ketegangan dan penyesuaian terus terjadi antara hubungan komunitas bank sampah dengan pengepul, seperti masalah harga yang tidak stabil, kecurangan, keterlambatan pengambilan sampah, masalah pembayaran yang tertunda, begitu pula persaingan di antara pengepul. Konflik antara pengurus bank sampah, dan berbagai permasalahan lainnya menempatkan peran DLH Tangsel sebagai mediator. Salah satu faktor yang tidak bisa diabaikan ketika terjadi konflik atau krisis adalah komunikasi. Krisis 
akan terjadi berkepanjangan apabila saluransaluran komunikasi dalam masyarakat tersumbat (Runtiko, Adi \& Novianti, 2015). DLH Tangsel juga pernah memfasilitasi forum yang mempertemukan pengurus bank sampah dan pengepul. Karena sebuah kebutuhan, para pengepul yang berjumlah 44 pengusaha di Tangerang Selatan juga terus beradaptasi dengan pertumbuhan bank sampah dengan menambah armada kendaraan pengangkut sampah, menambah tempat penampungan dan juga menambah jumlah karyawan, terutama pengepul yang dominan seperti Turmanto. Pengepul juga membangun jejaring dengan beberapa produsen dan industri daur ulang agar beragam jenis sampah dapat dibeli dari bank sampah. Kondisi ketegangan juga terjadi saat Yayasan Melati Bersih yang telah membangun jejaring bank sampah di Tangerang Selatan yang awalnya mempunyai relasi kerjasama dengan DLH Tangsel, memilih mundur dan pindah lokasi pengembangan bank sampah ke Bogor karena perannya sudah berkurang dan lebih didominasi oleh DLH Tangsel dengan membentuk Forum Komunikasi Bank Sampah (FORKAS) tahun 2014, yang terus berubah nama menjadi Silahturahmi Bank Sampah (SIBAS) tahun 2016, dan terakhir menjadi Perkumpulan Bank Sampah Tangerang Selatan (PERBAS) tahun 2020. DLH Tangsel juga membentuk pendamping bank sampah di setiap kecamatan dengan merekrut pengurus bank sampah yang aktif dan potensial yang bertugas untuk melakukan sosialisasi, pendampingan, dan pencatatan hasil penimbangan dari komunitas bank sampah.

Komunitas bank sampah terutama pengurus bank sampah yang datang dari partisipasi masyarakat yang memosisikan diri sebagai spirit kerelawanan, karena yang menjadi penggerak bank sampah khususnya pengurus bank sampah dalam jaringan triadik komunitas wacana menjadi dalam posisi yang tidak stabil, karena ada kondisi kejenuhan dan karena tidak ada insentif. Keaktifan pengurus bank sampah dilatarbelakangi beberapa faktor berdasarkan hasil pendalaman wawancara beberapa informan, yaitu: 1) Pengurus yang memang aktif di berbagai kegiatan sosial di masyarakat, seperti kader PKK, aktif di majelis taklim; 2) Tokoh masyarakat, seperti ketua RW, RT, dan seterusnya; 3) Ibu rumah tangga yang tidak ada aktivitas lain yang mengikat seperti pekerjaan penuh. Sementara pengurus yang melakukan aktivitas bank sampah dengan paruh waktu dan cenderung memiliki kesibukan yang mengikat maka ada kecenderungan terjadi seleksi alam dan ini tergambarkan dari hampir setengah komunitas bank sampah yang tidak aktif di kota Tangerang Selatan.

Di sisi lain ada kepentingan yang berbeda di antara stakeholder menyebabkan adanya gangguan (noise) yang menjadi hambatan dan kesenjangan sehingga menyebabkan kendala dalam keberlanjutan komunitas bank sampah, salah satu upaya adalah dengan terus membangun komunikasi lingkungan yang konvergen di mana harus mengedepankan komunikasi yang berupaya untuk membangun saling pengertian dengan posisi dan peran masing-masing pemangku kepentingan pada program bank sampah. Mendengarkan komentar dan keluhan yang dikemukakan antara pihak satu dan lainnya dalam relasi kovergensi apalagi saling turun langsung ke lapangan dan melihat dengan jernih akan membantu meredakan masalah (Perbawasari, Sjoraida \& Lestari, 2016). Sisi positif hadirnya bank sampah terbukti telah menjadi sarana dan ruang pendidikan lingkungan di masyarakat seperti perilaku memilah sampah dalam hal ini penerapan 3R, dan penanganan sampah mulai dari rumah tangga.

Berdasarkan relasi yang terjadi di antara ketiga kelompok tema lingkungan yang telah dipaparkan, membentuk sebuah model komunikasi yang saling ketergantungan dan memusat (konvergen) seperti pada Gambar 4 yang menjelaskan hubungan saling ketergantungan komunitas wacana yang memandang alam dengan perspektifnya masing-masing, yaitu: 1) A (Alam sebagai objek); 2) B (alam sebagai sumber); 3) C (alam sebagai spirit); 4) CE: Circular Economy (Ekonomi Sirkular). Komunitas kategori A adalah struktur yang melihat lingkungan secara objektif karena tugas dan wewenang serta pembuat kebijakan dan pelaksana kebijakan, yaitu pemerintah pusat, pemerintah daerah yang punya kebijakan secara teknis, sampai struktur dibawahnya (DLH Tangsel). 


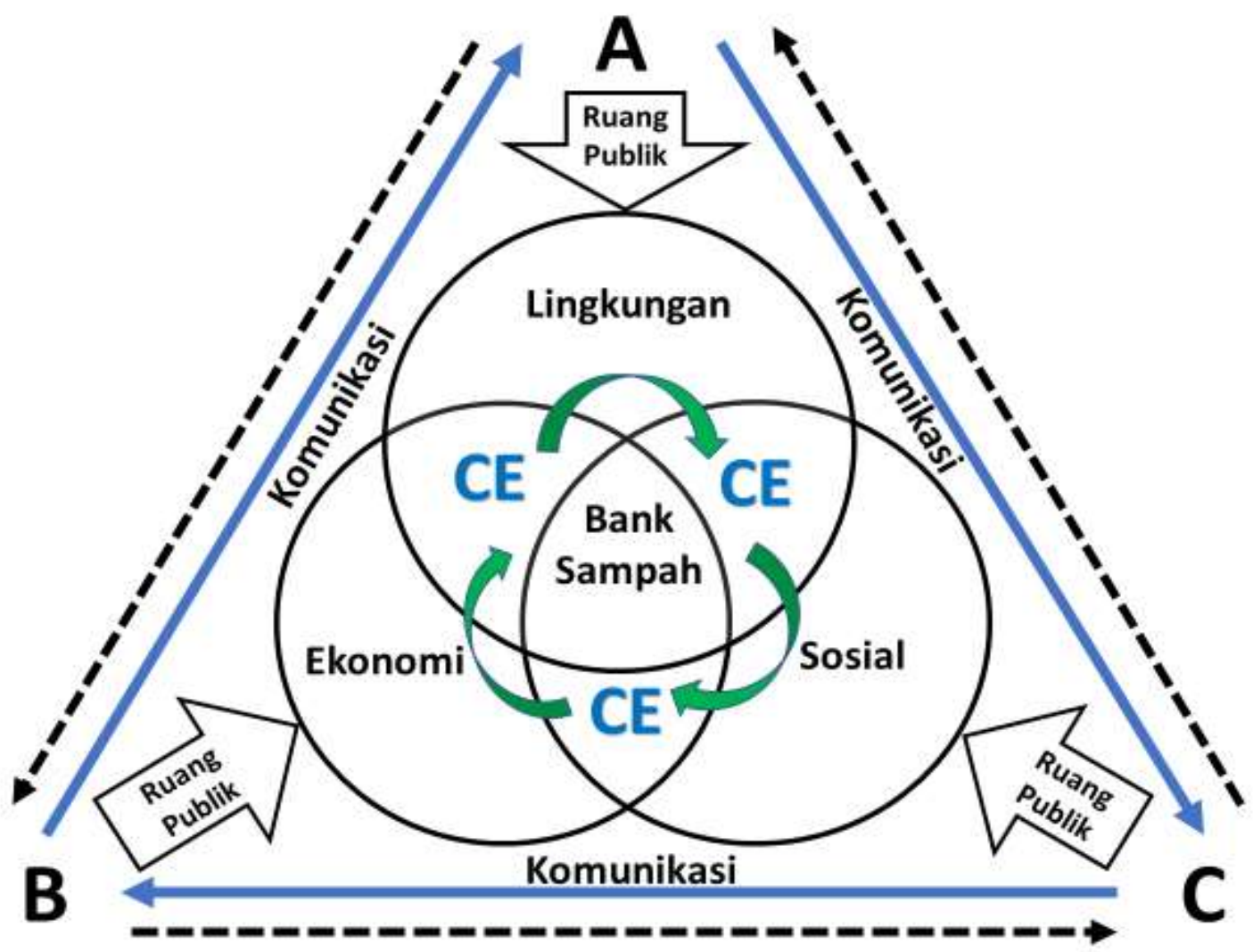

Sumber: Olah data peneliti (2019)

Gambar 4. Model Komunikasi Lingkungan Bank Sampah dalam Perspektif Pembangunan Berkelanjutan.

Komunitas kategori $\mathrm{B}$ terdiri dari komunitas yang memandang alam sebagai sumber, mereka mendapatkan kehidupan (nafkah) atau profit oriented dari keterlibatannya dengan masalah lingkungan, mulai dari pemulung, pengepul sampah, industri daur ulang, perusahaan, produsen yang memproduksi sampah, industri daur ulang dan pihak swasta lainnya yang profesional. Komunitas kategori $\mathrm{C}$ adalah mulai dari masyarakat suku pedalaman yang masih tinggal di alam terbuka/hutan, masyarakat adat yang masih memegang teguh nilai-nilai leluhur, kalangan pencinta lingkungan, relawan, aktivis lingkungan, Lembaga Swadaya Masyarakat (LSM), kalangan religius peduli lingkungan di mana mereka hadir dengan panggilan jiwa dan kerelawanan dalam hal menangani masalah lingkungan hidup.

Dari ketiga kategori tersebut memiliki kepentingan yang berbeda dalam keterlibatannya dengan masalah pengelolaan sampah, sehingga kadang terjadi ketegangan ketika kepentingan salah satu terhambat dengan kepentingan yang lainnya. DLH Tangsel atau pemerintah kota bergerak tergantung regulasi terutama dari anggaran pendapatan belanja daerah (APBD) dan dukungan kepada komunitas bank sampah adalah dengan memberikan sarana dan prasarana seperti timbangan dan gawangnya, buku tabungan, spanduk, dan ada tambahan alat pengomposan (composter) untuk pengelolaan sampah organiknya yang hasilnya adalah pupuk organik. Pendirian bank sampah juga mendapatkan legalitas melalui Surat Keputusan (SK) yang dikeluarkan oleh kelurahan. Selanjutnya dari sisi pengepul (swasta) dan juga industri daur ulang memiliki kepentingan ekonomi atau bisnis. Sementara posisi komunitas bank sampah lebih cenderung bersifat kerelawanan partisipasi masyarakat karena tidak ada insentif dari Pemkot Tangerang Selatan kepada pengurus bank sampah yang merupakan penggerak aktivitas program bank sampah, melainkan hanya margin sebesar 10 sampai dengan 15 persen dari hasil penimbangan yang biasanya hanya untuk biaya operasional dan administrasi. Relasi ketiga komunitas wacana A-B-C akan 
berkesinambungan dan berkelanjutan jika terjadi harmonisasi kepentingan, artinya semua kepentingan terakomodasi dalam sebuah program bank sampah.

Aktivitas yang berkelanjutan menciptakan arus komunikasi yang melingkar/memusat atau yang disebut model komunikasi konvergen (Flor \& Cangara, 2018) sesuai dengan proses ekonomi sirkular adanya aktivitas berwawasan 3R (reduce, reuse, recyle) yang melibatkan produsen, konsumen, pemerintah, pihak swasta (pengepul), dan perusahaan daur ulang. Proses tersebut membentuk lingkaran tertutup saling ketergantungan, sehingga dalam kondisi ketegangan ataupun konflik selalu menuju kepada penyesuaian dan adaptasi. Arus komunikasi berdasarkan Gambar 4 menjelaskan adanya proses komunikasi yang berbentuk lingkaran di antara komunitas wacana. Arus mulai A $\rightarrow \mathrm{B} \rightarrow \mathrm{C}$ kembali ke A dan berulang kembali (garis titik-titik) dan arus mulai dari $\mathrm{A} \rightarrow \mathrm{C} \rightarrow \mathrm{B}$ kembali ke $\mathrm{A}$ dan berulang terus-menerus berbentuk lingkaran tertutup.

\section{PENUTUP}

\section{Simpulan}

Komunikasi lingkungan dapat berupa bentuk mengampanyekan dan mengedukasi agar dapat berempati kepada masalah lingkungan yang salah satunya adalah masalah sampah, sampai pada menggerakkan masyarakat agar berperan aktif terlibat menjadi nasabah atau pengurus, sehingga program bank sampah dapat berjalan. Aktivitas ekonomi sirkular ada dua jenis, yaitu saat memilah sampah organik dan anorganik. Sampah organik akan mengalami pengomposan yang akhirnya menghasilkan pupuk organik yang bisa langsung dijual dan mendorong terbentuknya pertanian kota. Sampah anorganik biasanya langsung dijual ke pengepul, lalu hasil penjualannya masuk ke dalam tabungan nasabah bank sampah. Pengepul dengan motif bisnisnya (ekonomi) menjual sampah terpilah ke perusahaan daur ulang, sehingga pengepul sangat berperan sebagai jembatan konversi sampah menjadi tabungan nasabah bank sampah. Berjalannya program ini sangat tergantung pada insiasi dari DLH Tangsel dan partisipasi masyarakat, karena prinsipnya program bank sampah adalah sebuah rekayasa sosial (social engineering) dalam pengelolaan sampah berbasis partisipasi masyarakat yang berdampak menstimulus pemilahan sampah dari sumbernya, yaitu rumah tangga. Aktivitas ekonomi sirkular komunitas bank sampah yang utama adalah semangat nasabah untuk menabung dari hasil mengumpulkan sampah bernilai ekonomis menjadi rutinitas setiap bulannya. Selanjutnya berkembang juga dengan kegiatan lainnya seperti membuat kerajinan daur ulang sampah, seperti kreasi tas, bunga, taplak meja, ecobrick, dan lain-lain, sampai dengan pengolahan dari hasil pertanian kota, seperti salah satunya Bank Sampah Berlian di Kecamatan Pamulang yang telah mendirikan koperasi sekaligus menjadikan nasabahnya menjadi anggota koperasi.

Keberlanjutan program bank sampah di Kota Tangerang Selatan dapat disimpulkan pada konteks komunikasi lingkungan yang memiliki hubungan saling ketergantungan di antara relasi tiga komunitas wacana dalam sebuah model komunikasi konvergen, yaitu: 1) A (alam sebagai objek); 2) B (alam sebagai sumber); 3) C (alam sebagai sumber) dalam aktivitas ekonomi sirkular. Komunikasi lingkungan pada aktivitas ekonomi sirkular komunitas bank sampah di antara pemangku kepentingan pendukungnya mempertemukan peran-peran yang berbeda tapi saling mengisi sehingga idealnya akan membentuk komunikasi konvergen di mana terjadi upaya saling pengertian dengan perannya masingmasing (mutual understanding). DLH Tangsel sebagai pelaksana regulasi yang menyalurkan anggaran terkait program bank sampah seperti melakukan sosialisasi, pembinaan, dan menyediakan seperangkat alat penunjang seperti timbangan, gawang, dan buku tabungan secara gratis untuk komunitas bank sampah. Pengepul yang bersinggungan langsung dengan bank sampah memiliki motif bisnis karena sampah dimaknai sebagai komoditi yang terus diburu, maka posisinya stabil dalam relasi ini. Simpulan akhir bahwa program bank sampah sangat ditopang dari kolaborasi dan sinergi pola konfigurasi komunitas wacana pemerintah, bisnis, dan partisipasi masyarakat. 


\section{Saran}

Saran pada penelitian ini adalah kepada DLH Tangsel agar dapat melakukan evaluasi secara berkala yang melibatkan pemangku kepentingan terkait program bank sampah agar dapat mengidentifikasi dan menyelesaikan masalah yang terjadi dan mengantisipasi atau meminimalisir potensi konflik dan masalah di masa depan. Dari sisi kelembagaan, komunitas bank sampah memerlukan peningkatan kapasitas pengurus dan pengembangan kegiatan yang produktif dan inovatif. Hal ini dibutuhkan agar tidak menjadi kegiatan yang monoton seperti penimbangan rutin saja dan di sisi lain karena pengurus dan kader-kader yang tumbuh dari nasabah bank sampah merupakan modal sosial yang menjadi aset bagi kota Tangerang selatan yang fokus di bidang isu lingkungan. Selanjutnya saran dari sisi regenerasi atau kaderisasi sangat penting, karena selama ini pengurus bank sampah masih didominasi oleh perempuan yang berusia di atas 40 tahun, terutama ibu rumah tangga dan pensiunan yang merupakan bentuk pemberdayaan masyarakat. Hal ini perlu jadi pertimbangan terkait dengan keberlanjutan program bank sampah, karena temuan dalam penelitian ini juga menunjukkan belum adanya skema bagaimana proses pergantian kepengurusan dan rencana pengembangan bank sampah di masa depan agar menjadi bagian dari aktivitas yang mendukung kelestarian lingkungan dan meningkatkan partisipasi masyarakat yang lebih luas.

\section{DAFTAR PUSTAKA}

Aminudin, A. \& Manggolo, D. (2017) Program Bank Sampah Dan Pendapatan Keluarga Di Kecamatan Ciputat Timur Kota Tangerang Selatan. Liquidity. [Online] 6 (2), 133-140. Available from: doi:10.32546/lq.v6i2.32.

BBWS Ciliwung Cisadane (2020) Penanganan Longsor di TPA Cipeucang, Tangsel. [Online]. 2020. BBWS Ciliwung Cisadane. Available from: http://sda.pu.go.id/bbwscilicis/penangananlongsor-di-tpa-cipeucang-tangsel.

Cox, R. \& Pezzullo, P.C. (2015) Environmental Communication and the Public Sphere. 4th edition. London (GB), SAGE Publications.

Creswell, J.W. (2009) Research Design: Qualitative, Quantitative, and Mixed Methods
Approaches. 3rd edition. SAGE Publications.

Creswell, J.W. \& Poth, C.N. (2018) Qualitative Inquiry \& Research Design: Choosing Among Five Approaches. 4th edition. California, SAGE Publications.

DLH Tangsel (2020) Data Persampahan Dinas Lingkungan Hidup Tangerang Selatan.

DLH Tangsel (2019) Observasi Pra Penelitian (Catatan Lapangan).

Flor, A.G. (2004) Environmental Communication: Principles, Approaches and Strategies of Communication Applied to Environmental Management. Quezon City (PH), University of the Philippines Open University.

Flor, A.G. \& Cangara, H. (2018) Komunikasi Lingkungan: Penanganan Kasus-kasus Lingkungan Melalui Strategi Komunikasi. 1st edition. Jakarta (ID), Prenadamedia Group.

Haryanti, R. (2020) Koalisi Ekologis Sungai Cisadane Tuntut Rehabilitasi TPA Cipeucang. [Online]. 2020. Kompas.com. Available from: https://properti.kompas.com/read/2020/06/22/ 070000321/koalisi-ekologis-sungai-cisadanetuntut-rehabilitasi-tpa-cipeucang.

Hoesein, A. (2019) Bank Sampah Masalah dan Solusi. 1st edition. Jakarta, Syahadah.

Kabartangsel.com (2014) Walikota Tangsel: Kami Menargetkan Setiap RW Mempunyai Bank Sampah. [Online]. 2014. airinrachmidiany.com. Available from: $\mathrm{http} / /$ airinrachmidiany.com/walikota-tangselkami-menargetkan-setiap-rw-mempunyaibank-sampah.

Killingsworth, M.J. \& Palmer, J.S. (2012) Ecospeak: Rhetoric and Environmental Politic in America. 1st edition. Carbondale \& Edwardsville (US), Southern Illinois University Press.

Kincaid, D.L. (1979) The Convergence Model of Communication. In: Papers of The East-West Communication Institute. Honolulu, EastWest Communication Institute. p.

McManus, M.M. (1996) Environmental Communication: Theory And Practice. New Jersey Institute of Technology.

Naess, A. (1973) The shallow and the deep, longrange ecology movement. A summary*. Inquiry. [Online] 16 (1-4), 95-100. Available from: doi:10.1080/00201747308601682.

Perbawasari, S., Sjoraida, D.F. \& Lestari, V.A. (2016) Proses Public Relations Dalam Program Gerakan Pungut Sampah Pemerintah Kota Bandung. Jurnal Penelitian Komunikasi. [Online] 19 (2), 95-108. Available from: doi:10.20422/jpk.v19i2.59.

Runtiko, A.G., Adi, T.N. \& Novianti, W. (2015) Krisis dan Komunikasi pada Masyarakat 
Miskin Perdesaan. Jurnal Penelitian

Komunikasi. [Online] 18 (1), 1-14. Available from: doi:10.20422/jpk.v18i1.16.

Wimmer, R.D. \& Dominick, J.R. (2011) Mass Media Research: An Introduction. 9th edition.
Boston, Wadsworth, Cengage Learning.

Yin, R.K. (2012) Application of Case Study Research. 3rd edition. London, SAGE Publications. 